\title{
Short-term effect of adenotonsillectomy on growth and nutritional anthropometric parameters of children with obstructive adenotonsillar enlargement
}

Ayotunde James Fasunla* $\mathbb{D}^{*}$, Ebidisemere Linda Totyen, Paul Adekunle Onakoya and Onyekwere George Nwaorgu

\begin{abstract}
Background: Obstructive adenotonsillar enlargement is known to cause failure to thrive in children. The effect of adenotonsillectomy is not well documented on the growth of affected children. The study was carried out to investigate the effect of adenotonsillectomy on growth of children with obstructive adenotonsillar enlargement. It was a quasi-experimental study consisting of 62 children ( $\leq 12$ years) with obstructive adenotonsillar enlargement and 62 healthy controls. Variables measured at baseline, sixth week and 13th week post adenotonsillectomy, were weight, height, mid-upper arm circumference, and triceps skinfold thickness. The percent of weight-for-age and height-for-age were, respectively, calculated by dividing the child's weight and height by the median expected weight and height (i.e., the 50th percentile) based on the child's chronological age. The obtained weight-for-age and height-for-age values were used to determine the presence of failure to thrive and stunting, respectively.
\end{abstract}

Results: Majority (70.6\%) of the patients with malnutrition were from a low socioeconomic class. At baseline, failure to thrive and stunting were found among 17 (26.4\%) cases and $11(17.7 \%)$ controls, but the proportion reduced to six (9.7\%) and three (4.8\%), respectively, at the 13th week post adenotonsillectomy. There was a steady increase in weight-for-age, height-for-age, mid-upper arm circumference, and triceps skinfold thickness in both cases and controls from baseline to the 13th week. However, there was a significant difference in percentage variation of these variables between the two groups.

Conclusions: Adenotonsillectomy improved the growth of children with obstructive adenotonsillar enlargement and hence recommended in cases with failure to thrive and stunting.

Keywords: Adenotonsillectomy, Failure to thrive, Obstructive adenotonsillar hyperplasia, Stunting

\section{Background}

Adenoids and palatine tonsils are lymphoid tissues located at the pharyngeal portion of the upper aero-digestive tract. They form part of the body's first line of defense against infection and are involved in both cellular and humoral immunity. Acute and chronic antigenic stimulation of these tissues by bacteria, viruses, food, and environmental irritants results in both local and systemic antibody production [1-3]. Inflammation, infection, and allergic

\footnotetext{
*Correspondence: ayofasunla@yahoo.com

Department of Otorhinolaryngology, College of Medicine, University of Ibadan and University College Hospital, PMB 5116, Ibadan, Oyo State 200212, Nigeria
}

stimulation of follicles of these lymphoid tissues usually result in their cellular hyperplasia and enlargement, thus causing varied degrees of pharyngeal airway obstruction $[4,5]$. The symptoms of obstruction caused by the enlarged lymphoid tissues result not only from their actual size, but also from their relative disproportional size to nasopharyngeal and/or oropharyngeal airway space $[6,7]$.

Adenotonsillar enlargement is the most common cause of upper airway obstruction and sleep-disordered breathing in children [8-11]. The enlarged adenoids alter nasal airflow with resultant mouth breathing. The persistent mouth breathing leads to changes in their muscular vectors with resultant negative effects on mid-facial growth. 
The overall effects are narrowed palate, crowded nasopharynx, and an abnormally positioned mandible, the socalled "adenoid facies" [12].

Obstructive adenotonsillar enlargement, when associated with sleep-disordered breathing in children, may cause failure to thrive [8-10]. The pathophysiology can be explained with reduced nocturnal secretion of growth hormone, hypoxemia, nocturnal respiratory acidosis, sleep related increase in respiratory effort, excessive calorie utilization, and poor feeding from anorexia, dysphagia, or disturbances of olfaction [13, 14]. The effect of failure to thrive may be more pronounced in developing countries, where malnutrition is still a problem [15].

Surgical removal of the obstructive, enlarged adenoid, and/or tonsils is hypothesized to prevent and reverse failure to thrive/malnutrition and stunting in the affected children. There is paucity of literature on the effect of adenotonsillectomy on the growth and anthropometric parameters of children with obstructive adenotonsillar enlargement, hence the relevance of this study.

\section{Methods \\ Study design}

This was a prospective hospital-based quasi-experimental study of children aged 12 years and below. The study was approved by the Institutional Ethics Review Committee (UI/EC/12/0045). Written permission was obtained from the State Ministry of Education and head teachers of the purposively selected schools. Informed consent was also obtained from the parents of all the participants. Data collection was done in accordance with the Helsinki Declaration of 1975 as revised in 1996.

\section{Sampling method}

Cases were children with clinical and radiological diagnosis of obstructive adenotonsillar enlargement at the health institution where the study was conducted. The controls were healthy children matched for age and sex with the cases recruited from two nursery and primary schools in Ibadan. The patients were consecutively recruited into the study over 10 months (August 2012June 2013). Exclusion criteria included children with craniofacial abnormality, congenital cardiac anomaly, bronchiolitis/asthma, low birth weight (less than $1.5 \mathrm{~kg}$ ), endocrinal, and chronic systemic diseases.

\section{Data collection procedures and intervention}

A Study Proforma was used to obtain and document participants' demographic data, occupation of parents, and clinical symptoms of obstructive adenotonsillar enlargement, which included nasal obstruction, mucoid/mucopurulent nasal discharge, mouth breathing, snoring, sleep apnoea, failure to thrive, and ear symptoms. The socioeconomic stratification of the participants was determined by the occupational strata of their parent with highest pay [16]. The socioeconomic class was classified into high (occupational classes I and II), middle (occupational class III), and low (occupational classes IV and V).

\section{Determination of adenoid and tonsillar enlargement}

The oropharyngeal examination was also performed to determine the size of the palatine tonsils using Brodsky grading method [17]. Plain lateral postnasal space radiograph was done in all the cases. Adenoid enlargement was considered obstructive if the adenoid-nasopharyngeal ratio was more than 0.71 on the film $[18,19]$. The adenoidnasopharyngeal ratio is calculated using the Fujioka method by dividing the distance from the outermost point of convexity of adenoid shadow to basiocciput with the distance between spheno-basi-occiput and posterior end of hard palate [20].

\section{Anthropometric measurements}

The weight, height, mid-upper arm circumference (MUAC), and triceps skinfold thickness (TSFT) of all the participants were measured at baseline, 6, and 13 weeks. For the cases, baseline measurement was taken on the eve of adenotonsillectomy procedure. Thereafter, the percentage of weight-for-age was calculated by dividing the child's weight by the median expected weight (i.e., the 50th percentile) [21]. The median expected weight was calculated based on the child's chronological age using the formula $2 N+8$, where $N$ is the age of the child. The obtained percentage of weight-for-age value was then compared with parameter from the Gomez classification (weight-for-age) [ 21] to determine the child's nutritional status. A weight-for-age value of more than $120 \%$ is obese, $110-119 \%$ is overweight, and 90 $109 \%$ is normal. The weight-for-age score below $90 \%$ is regarded as malnutrition or failure to thrive. Mild malnutrition is $75-89$ (grade I), moderate malnutrition is $60-74 \%$ (grade II), and severe malnutrition is less than $60 \%$ (grade III). Similarly, the percentage of height-forage was calculated by dividing the child's height by the median expected height (i.e., the 50th percentile) [22]. The median expected height was calculated based on the child's chronological age using the formula $7 N+77$, where $N$ is the age of the child. The obtained percentage of height-for-age was then compared with parameter from the Waterlow classification (height-for-age) [22] to determine the degree of stunting if present. A heightfor-age value more than $95 \%$ is regarded as normal, 90 $95 \%$ is mild stunting, $85-90 \%$ is moderate stunting, and less than $85 \%$ is severe stunting.

The MUAC was measured at the midpoint between the acromion and olecranon processes of each child. Participants with MUAC values less than $12.5 \mathrm{~cm}$ or less than 2 
SD (- $2 \mathrm{SD})$ for his/her age and sex were regarded as having a failure to thrive [23].

The TSFT was measured in centimeters $(\mathrm{cm})$ at the midpoint distance between acromion and olecranon processes of the nondominant hand with the elbow extended [24]. The skinfold was pulled away from the muscle and measured with a caliper. Patients with TSFT values of less than the 50th percentile for his/ her age and sex were regarded as having a failure to thrive [25].

\section{Statistical analysis}

Data collected were inputted into the statistical package for social sciences (IBM SPSS, Armonk, New York, USA) version 17 for analysis. Summary statistics was done using means and SD (standard deviations). Demographic and clinical variables were presented in tables and charts. Anthropometric measurements of the patients with obstructive adenotonsillar enlargement were compared with that of the controls at baseline, sixth, and 13th week using Students $t$ test. The percentage variations for all the anthropometric measurements were computed using the Wilcoxon signed-rank test. The level of statistical significance was set at $P$ value of less than 0.05 .

\section{Results}

There were 62 cases comprising 39 (63\%) males and 23 (37\%) females. There were 62 controls comprising 31 (50\%) males and 31 (50\%) females. The mean age of the cases and controls were $3.8 \pm 0.72$ years and $3.8 \pm 0.23$ years, respectively. The socioeconomic status and preoperative (baseline) nutritional status of the patients based on Gomez classification (weight-for-age) are shown in Table 1. None was observed to be severely

Table 1 Parental socioeconomic status and pre-operative nutritional status of children with obstructive adenotonsillar enlargement

\begin{tabular}{lllll}
\hline Nutritional status & \multicolumn{4}{l}{ Socioeconomic status } \\
\cline { 2 - 5 } & High & Middle & Low & $\begin{array}{l}\text { Total } \\
{[n(\%)]}\end{array}$ \\
\hline Obese (> 120\%) & 4 & 0 & 1 & $5(8.1 \%)$ \\
Overweight (110-119\%) & 3 & 1 & 2 & $6(9.7 \%)$ \\
$\quad$ Normal (90-109\%) & 12 & 7 & 15 & $34(54.8 \%)$ \\
$\quad$ Mild (75-89\%) & 1 & 2 & 8 & $11(17.7 \%)$ \\
$\quad$ grade I malnutrition) & & & & \\
$\quad$ Moderate (60-74\%) & 1 & 1 & 4 & $6(9.7 \%)$ \\
$\quad$ grade II malnutrition) & & & & \\
Total [n (\%)] & 21 & 11 & 30 & 62 \\
& $(33.9 \%)$ & $(17.7 \%)$ & $(48.4 \%)$ & $(100.0 \%)$ \\
\hline
\end{tabular}

Note: The nutritional status was according to Gomez classification (weight-for-age) malnourished. Participants belonging to the low socioeconomic status were 30 (48.4\%); middle socioeconomic status was $11(17.7 \%)$, and high socioeconomic class was 21(33.9\%). There were 17 cases with malnutrition and $12(70.6 \%)$ of them were from low socioeconomic class (Table 1).

The mean weight of both the cases and controls progressively increased from baseline to the 13th week period. However, the most significant weight increase for the cases occurred from the sixth week to 13th week (Table 2). Similarly, their mean height and TSFT also progressively increased from baseline to 13th week. Initially, the mean MUAC of the cases decreased from $16.95 \pm 2.61 \mathrm{~cm}$ at baseline to $15.76 \pm 2.73 \mathrm{~cm}$ at the sixth week, but later increased to $16.29 \pm 2.81 \mathrm{~cm}$ at the 13th week post-adenotonsillectomy (Table 2). In the controls, the parameters increased steadily in values from $16.16 \pm 1.87 \mathrm{~cm}$ at baseline to $16.62 \pm 2.33 \mathrm{~cm}$ at the 13th week (Table 2).

The percentage variations in the weight of cases and controls are shown in Table 3. At the sixth week, 43 cases had a significant weight increase as against 45 controls while at 13th week, 54 cases had a significant weight increase as against 47 controls. However, the difference in percentage variation in weight between the cases and controls was more marked at the 13th week than at sixth week as shown in Table 3.

Table 2 Comparison between anthropometric measurements of cases and controls

\begin{tabular}{|c|c|c|c|c|}
\hline $\begin{array}{l}\text { Anthropometric } \\
\text { measurements }\end{array}$ & $\begin{array}{l}\text { Period of } \\
\text { measurement }\end{array}$ & $\begin{array}{l}\text { Cases } \\
\text { Mean } \pm \text { SD }\end{array}$ & $\begin{array}{l}\text { Controls } \\
\text { Mean } \pm \text { SD }\end{array}$ & $P$ value \\
\hline \multirow[t]{3}{*}{ Weight (kg) } & Baseline & $17.14 \pm 9.04$ & $16.82 \pm 7.60$ & 0.2105 \\
\hline & $\begin{array}{l}6 \text { weeks } \\
\text { post-op }\end{array}$ & $17.84 \pm 9.05$ & $17.29 \pm 7.74$ & 0.3578 \\
\hline & $\begin{array}{l}13 \text { weeks } \\
\text { post-op }\end{array}$ & $20.02 \pm 3.87$ & $17.79 \pm 7.98$ & 0.9477 \\
\hline \multirow[t]{3}{*}{ Height (cm) } & Baseline & $98.32 \pm 10.48$ & $96.35 \pm 17.14$ & 0.7596 \\
\hline & $\begin{array}{l}6 \text { weeks } \\
\text { post-op }\end{array}$ & $99.89 \pm 10.39$ & $97.38 \pm 17.12$ & 0.9709 \\
\hline & $\begin{array}{l}13 \text { weeks } \\
\text { post-op }\end{array}$ & $101.37 \pm 21.77$ & $97.96 \pm 16.99$ & 0.9565 \\
\hline \multirow[t]{3}{*}{ MUAC (cm) } & Baseline & $16.95 \pm 2.61$ & $16.16 \pm 1.87$ & 0.3490 \\
\hline & $\begin{array}{l}6 \text { weeks } \\
\text { post-op }\end{array}$ & $15.76 \pm 2.73$ & $16.56 \pm 1.93$ & 0.8535 \\
\hline & $\begin{array}{l}13 \text { weeks } \\
\text { post-op }\end{array}$ & $16.29 \pm 2.81$ & $16.62 \pm 2.33$ & 0.7002 \\
\hline \multirow[t]{3}{*}{ TSFT (mm) } & Baseline & $10.91 \pm 4.37$ & $10.74 \pm 1.98$ & 0.2745 \\
\hline & $\begin{array}{l}6 \text { weeks } \\
\text { post-op }\end{array}$ & $11.59 \pm 3.78$ & $11.21 \pm 2.14$ & 0.6776 \\
\hline & $\begin{array}{l}13 \text { weeks } \\
\text { post-op }\end{array}$ & $11.91 \pm 3.87$ & $11.67 \pm 2.18$ & 0.4186 \\
\hline
\end{tabular}

Footnote: MUAC mid-upper arm circumference, TSFT triceps skinfold thickness 
Table 3 Percentage variations in weight of participants at the 6th and 13th week

\begin{tabular}{|c|c|c|c|c|c|}
\hline \multirow{2}{*}{$\begin{array}{l}\text { Follow-up } \\
\text { period }\end{array}$} & \multicolumn{2}{|c|}{ Cases $(n=60)$} & \multicolumn{2}{|c|}{ Controls $(n=60)$} & \multirow{2}{*}{$\begin{array}{l}P \\
\text { value }\end{array}$} \\
\hline & Frequency & $\%$ Variation & Frequency & $\%$ Variation & \\
\hline \multirow[t]{3}{*}{ At 6th week } & $3^{a}$ & 24.20 & $3^{a}$ & 31.00 & \multirow[t]{3}{*}{0.00} \\
\hline & $43^{b}$ & 40.00 & $45^{\mathrm{b}}$ & 38.90 & \\
\hline & $16^{c}$ & & $14^{c}$ & & \\
\hline \multirow[t]{3}{*}{ At 13th week } & $1^{a}$ & 12.90 & $0^{a}$ & 0.00 & \multirow[t]{3}{*}{0.00} \\
\hline & $54^{\mathrm{b}}$ & 45.80 & $47^{b}$ & 38.70 & \\
\hline & $7^{c}$ & & $15^{c}$ & & \\
\hline
\end{tabular}

$n$ number of participants. ${ }^{\mathrm{a}}$ Decrease. ${ }^{\mathrm{b}}$ Increase. ${ }^{\mathrm{c}}$ Same

At the sixth week, 51 cases had a significant height increase as against 56 controls while at 13th week, 55 cases had a significant weight increase as against 49 controls. However, the difference in percentage variation of height between the cases and controls was also more marked at the 13th week than at sixth week as shown in Table 4.

There was no significant increase in MUAC of children with obstructive adenotonsillar enlargement when compared with controls at the sixth week $(P=0.10)$. However, this difference was significant at the 13th week as shown in Table 5. There was no significant increase in TSFT between cases and controls at both sixth and 13th week as shown in Table 6 . The number of patients with failure to thrive or malnutrition and stunting is shown in Table 7.

\section{Discussion}

This study showed that adenotonsillectomy could improve growth, prevent failure to thrive, and stunting in children with obstructive adenotonsillar enlargement. To the best of our knowledge, this is the first study that investigated the effect of adenotonsillectomy on growth of children in sub-Saharan Africa where there is poverty. The finding from this study supports the report that surgical removal of the anatomic structures causing pharyngeal airway obstruction will improve the growth of the affected children [26-29].

Table 4 Percentage variation in height of participants at the 6th and 13th week

\begin{tabular}{|c|c|c|c|c|c|}
\hline \multirow{2}{*}{$\begin{array}{l}\text { Follow-up } \\
\text { period }\end{array}$} & \multicolumn{2}{|c|}{ Patients $(n=60)$} & \multicolumn{2}{|c|}{ Controls $(n=60)$} & \multirow{2}{*}{$\begin{array}{l}P \\
\text { value }\end{array}$} \\
\hline & Frequency & \% Variation & Frequency & $\%$ Variation & \\
\hline \multirow[t]{3}{*}{ At 6th week } & $2^{a}$ & 21.70 & $2^{a}$ & 76.90 & \multirow[t]{3}{*}{0.00} \\
\hline & $51^{\mathrm{b}}$ & 46.50 & $56^{b}$ & 44.40 & \\
\hline & $9^{c}$ & & $4^{c}$ & & \\
\hline \multirow[t]{3}{*}{ At 13th week } & $3^{a}$ & 29.00 & $5^{a}$ & 55.50 & \multirow[t]{3}{*}{0.00} \\
\hline & $55^{b}$ & 48.50 & $49^{b}$ & 42.70 & \\
\hline & $4^{c}$ & & $8^{c}$ & & \\
\hline
\end{tabular}

$n$ number of participants. ${ }^{\mathrm{a}}$ Decrease. ${ }^{\mathrm{b}}$ Increase. ${ }^{\mathrm{C}}$ Same
Table 5 Percentage variation in mid-upper arm circumference of participants at the 6th and 13th week

\begin{tabular}{|c|c|c|c|c|c|}
\hline \multirow{2}{*}{$\begin{array}{l}\text { Follow-up } \\
\text { period }\end{array}$} & \multicolumn{2}{|c|}{ Patients $(n=60)$} & \multicolumn{2}{|c|}{ Controls $(n=60)$} & \multirow{2}{*}{$\begin{array}{l}P \\
\text { value }\end{array}$} \\
\hline & Frequency & $\overline{\% \text { Variation }}$ & Frequency & $\overline{\% \text { Variation }}$ & \\
\hline \multirow[t]{3}{*}{ At 6th week } & $14^{a}$ & 28.50 & $4^{a}$ & 49.40 & \multirow[t]{3}{*}{0.10} \\
\hline & $20^{b}$ & 28.10 & $51^{\mathrm{b}}$ & 44.90 & \\
\hline & $28^{c}$ & & $7^{c}$ & & \\
\hline \multirow[t]{3}{*}{ At 13th week } & $1^{\mathrm{a}}$ & 25.80 & $5^{a}$ & 40.60 & \multirow[t]{3}{*}{0.00} \\
\hline & $43^{b}$ & 42.10 & $48^{b}$ & 36.70 & \\
\hline & $18^{\mathrm{c}}$ & & $9^{c}$ & & \\
\hline
\end{tabular}

$n$ number of participants. ${ }^{\mathrm{a}}$ Decrease. ${ }^{\mathrm{b}}$ Increase. ${ }^{\mathrm{C}}$ Same

The improvement in weight-for-age and height-forage of these patients following adenotonsillectomy may not be unconnected to cessation of labored breathing, which usually consumes the available body calorie, thereby promoting improved feeding and sleeping patterns. The preoperative stunting in the patients could be explained by similar factors that caused failure to thrive or malnutrition [10, 28]. However, the determination of the levels of serum insulin-like growth factor 1, insulinlike growth factor-binding protein 3, and ghrelin before and after adenotonsillectomy could have further confirmed the postoperatively improvement in growth but it is beyond the scope of this study. The mean weight, height, and TSFT of the participants increased steadily from baseline to the 13th week of investigation. In this present study, the mean MUAC of cases reduced from baseline to the sixth week post-adenotonsillectomy before it increased thereafter. The reason for this initial decrease in mean MUAC is unknown.

Tables 3, 4, 5 showed progressive decrease in the number of patients with failure to thrive and stunting. This corroborated the findings from a similar study in Finland [27], but another similar study recorded an increase only in the mean weight but not in height after adenotonsillectomy [10]. It is only in TSFT that there was a progressive decrease in the number of patients with values less than the 50th percentile for age and sex. It is expected that increased appetite or reduced

Table 6 Percentage variation in triceps skinfold thickness of participants at the 6th and 13th week

\begin{tabular}{|c|c|c|c|c|c|}
\hline \multirow{2}{*}{$\begin{array}{l}\text { Follow-up } \\
\text { period }\end{array}$} & \multicolumn{2}{|c|}{ Patients $(n=60)$} & \multicolumn{2}{|c|}{ Controls $(n=60)$} & \multirow{2}{*}{$\begin{array}{l}P \\
\text { value }\end{array}$} \\
\hline & Frequency & $\%$ Variation & Frequency & $\%$ Variation & \\
\hline \multirow[t]{3}{*}{ At 6th week } & $6^{a}$ & 45.60 & $2^{a}$ & 18.80 & \multirow[t]{3}{*}{0.08} \\
\hline & $39^{b}$ & 35.80 & $48^{b}$ & 42.10 & \\
\hline & $17^{c}$ & & $12^{c}$ & & \\
\hline \multirow[t]{3}{*}{ At 13th week } & $7^{a}$ & 32.00 & $2^{a}$ & 26.60 & \multirow[t]{3}{*}{0.19} \\
\hline & $34^{b}$ & 34.30 & $52^{b}$ & 44.90 & \\
\hline & $21^{c}$ & & $8^{c}$ & & \\
\hline
\end{tabular}

$n$ number of participants. ${ }^{a}$ Decrease. ${ }^{b}$ Increase. ${ }^{\text {CSame }}$ 
Table 7 Patients with failure to thrive and stunting

\begin{tabular}{lll}
\hline Period of study & Failure to thrive & Stunting \\
\hline At baseline & $17(26.4 \%)$ & $11(17.7 \%)$ \\
At 6th week & $8(12.9 \%)$ & $8(12.9 \%)$ \\
At 13th week & $6(9.7 \%)$ & $3(4.8 \%)$ \\
\hline
\end{tabular}

nighttime caloric expenditure from labored breathing should cause an increase in fat accumulation after adenotonsillectomy in children with obstructive adenotonsillar enlargement. This should translate to an increase in TSFT, as it is a measure of fat mass.

Obstructive sleep apnoea causes both daytime and nocturnal sleep disturbance. There is sleep fragmentation, restlessness, and multiple arousals from the effect of hypercapnemia and hypoxemia. This alters the quality and length of rapid-eye movement sleep with the resultant reduction in growth hormone production which is elaborated at this phase of sleep [30]. The poor sleeping pattern is also associated with neurocognitive and behavioral changes such as hyperactivity, attention-deficit disorders, aggression, poor socialization, and poor school performance (specifically deficits in memory, learning, and problem-solving skill) [31]. The effect of adenotonsillectomy on neurocognitive and behavioral changes is beyond the scope of this study.

Male preponderance of cases seen in this study is similar to what had earlier been reported in similar studies [32-34]. Majority (48.4\%) patients had parents in the low socioeconomic class, and this is similar to reports from similar studies in the USA and China [35-37]. Poor ventilation system in houses occupied by these children may predispose them to recurrent upper airway infection with development of obstructive adenotonsillar hyperplasia. Few studies in the USA have implicated the black race and African American origin as a risk factor for sleep-disordered breathing, and majority of African American parents are in the low socioeconomic class [35, 38-41]. Twenty-one (33.8\%) patients in high socioeconomic class constituted the second highest group. This observation may be by chance or due to allergic stimulation of the adenoid and tonsils by infant formula feeds, which is a common practice among children of the workingclass mothers. A low socioeconomic status is strongly associated with sleep-disordered breathing and malnutrion [35]. More than two thirds (70.6\%) of the cases with malnutrition were from low socioeconomic class. Inadequate nutrition and imbalanced diet due to financial constraints may have contributed. A low socioeconomic class has been associated with poor health-seeking behavior and is less likely to be aware of the disease and its deleterious nutritional complications.

\section{Conclusion}

Adenotonsillectomy is found to improve weight, height, and MUAC in children with obstructive adenotonsillar enlargement. It is therefore recommended in children with obstructive adenotonsillar enlargement complicated with the failure to thrive and stunting. Targeted and well-coordinated health education to create awareness on adenotonsillar enlargement as a cause of failure to thrive and stunting among parents is advocated.

\section{Abbreviations}

MUAC: Mid-upper arm circumference; SD: Standard deviation; TSFT: Triceps skinfold thickness

\section{Acknowledgements}

Not applicable.

\section{Authors' contributions}

AJF contributed to the study concept and design, data collection, analysis and interpretation, writing of the manuscript, revision, and final draft approval. ELT contributed to the study design, data collection, manuscript drafting, and final draft approval of the manuscript. PAO contributed to the study design, data analysis, manuscript drafting, and final draft approval of the manuscript. OGN contributed to the study concept and design, manuscript review for contribution to knowledge and correction, and final draft approval. All authors read and approved the final manuscript.

Funding

There was no funding support to conduct the study. It was self-sponsored.

Availability of data and materials

The datasets used and/or analyzed during the current study are available from the corresponding author on reasonable request.

\section{Ethics approval and consent to participate}

Ethical approval was obtained to conduct the study from Ethical Review Committee of Joint University of Ibadan/University College Hospital, Ibadan, Nigeria (UI/EC/12/0045). Written permission was obtained from the State Ministry of Education and head teachers of the purposively selected schools. Written informed consent was also obtained from the parents of all the participants. Data collection was done in accordance with the Helsinki Declaration of 1975 as revised in 1996.

Consent for publication

Not applicable

Competing interests

The authors declare that they have no competing interests.

Received: 21 October 2019 Accepted: 30 December 2019

Published online: 17 February 2020

References

1. Arita M, Kodama S, Suzuki M, Mogi G (2003) Single cell analysis of adenoid CD5+ B cells and their protective contributions to nasopharyngeal immunity. Laryngoscope 113:484-491

2. Abu Bakar M, McKimm J, Haque SZ, Majumder MAA, Haque M (2018) Chronic tonsillitis and biofilms: a brief overview of treatment modalities. J Inflamm Res. 11:329-337

3. Goldbart AD, Goldman JL, Li RC, Brittian KR, Tauman R, Gozai D (2004) Differential expression of cysteinyl leukotriene receptors 1 and 2 in tonsils of children with obstructive sleep apnea syndrome or recurrent infection. Chest 126:13-18

4. Tosca MA, Riccio AM, Marseglia GL, Caligo G, Pallestrini E, Ameli F et al (2001) Nasal endoscopy in asthmatic children: assessment of rhinosinusitis and adenoiditis incidence, correlations with cytology and microbiology. Clin Exp Allergy 31:609-615 
5. Brambilla I, Pusateri A, Pagella F, Caimmi D, Caimmi S, Licari A et al (2014) Adenoids in children: advances in immunology, diagnosis, and surgery. Clin Anat. 27:346-352

6. Zhu J, Fang Y, Wang H, Chen X, Yu D, Shen Y (2015) Insulin-like growth factor-1 and insulin-like growth factor-binding protein-3 concentrations in children with obstructive sleep apnea-hypopnea syndrome. Respir Care. 60:593-602

7. Orji FT, Ezeanolue BC (2008) Evaluation of adenoidal obstruction in children: clinical symptoms compared with roentgenographic assessment. J Laryngol Otol 122:1201-1205

8. Kang JM, Auo HJ, Yoo YH, Cho JH, Kim BG (2008) Changes in serum levels of IGF-I in growth following adenotonsillectomy in children. Int J Pediatr Otorhinolaryngol 72:1065-1069

9. Ersoy B, Yuceturk AV, Taneli F, Urk V, Uyanik BS (2005) Changes in growth pattern, body composition and biochemical markers of growth after adenotonsillectomy in prepubertal children. Int J Pediatr Otorhinolaryngol 69:1175-1181

10. Gümüssoy M, Atmaca S, Bilgici B, Unal R (2009) Changes in IGF-I, IGFBP-3 and ghrelin levels after adenotonsillectomy in children with sleep disordered breathing. Int J Pediatr Otorhinolaryngol 73:1653-1656

11. Bailey CM, Croft CB (1997) Sleep apnoea. In: Kerr AG, Adams DA, Cinnamond MJ (eds) Scott-Brown's otorhinolaryngology, 6th edn. Butterworth-Heinemann Publications, Oxford

12. Valera FC, Travitzki LV, Mattar SE, Matsumoto MA, Elias AM, AnselmoLima WT (2003) Muscular, functional and orthodontic changes in preschool children with enlarged adenoids and tonsils. Int J Pediatr Otorhinolaryngol 67:761-770

13. Bland RM, Bulgarelli S, Ventham JC, Jackson D, Reilly JJ, Paton JY (2001) Total energy expenditure in children with obstructive sleep apnoea syndrome. Eur Respir J 18:164-169

14. Altundag A, Salihoglu M, Cayonu M, Tekeli H (2014) Clinical assessment of olfactory functions in children who underwent adenotonsillectomy during pre- and post-operative period. Int J Pediatr Otorhinolaryngol 78:1138-1142

15. Eze UIH, Olowu AA, Bamidele TO, Adeyanju FD (2005) Prevalence of malnutrition and effects of maternal age, education and occupation amongst preschool children attending health centres in a semi urban area of southwestern Nigeria. NQJHM 15:179-183

16. Famuyiwa OO, Olorunshola DA, Derin A (1998) Some family factors in sickle cell anaemia in Lagos, Nigeria. Nig Med Practitioner 35:70-73

17. Brodsky $L$ (1989) Modern assessment of tonsils and adenoids. Pediatr Clin North Am 36:1551-1569

18. Adedeji TO, Amusa YB, Aremu AA (2016) Correlation between adenoidal nasopharyngeal ratio and symptoms of enlarged adenoids in children with adenoidal hypertrophy. Afr J Paediatr Surg 13(1):14-19

19. Kolo ES, Salisu AD, Tabari AM, Dahilo EA, Aluko AA (2010) Plain radiographic evaluation of the nasopharynx: do raters agree? Int J Pediatr Otorhinolaryngol 74:532-534

20. Fujioka M, Young LW, Girdany BR (1979) Radiographic evaluation of adenoidal size in children: adenoidal-nasopharyngeal ratio. Am J Roentgenol 133:401-404

21. Gomez F, Galvan RR, Cravioto J, Frenk S (1955) Malnutrition in infancy and childhood, with special reference to kwashiorkor. Adv Pediatr 7:131-169

22. Waterlow JC (1972) Classification and definition of protein-calorie malnutrition. Br Med J 3:566-569

23. Oredugba FA, Savage KO (2002) Anthropometric finding in Nigerian children with sickle cell disease. Pediatr Dent 24:321-325

24. Sungurtekin HL, Sungurtekin U, Hanci V, Erdem E (2004) Comparison of two nutrition assessment techniques in hospitalized patients. Nutrition 20:428-432

25. Addo OY, Himes JH (2010) Reference curves for triceps and subscapular skinfold thicknesses in US children and adolescents. Am J Clin Nutr 91:635-642

26. Selimoglu E, Selimoglu MA, Orbak Z (2003) Does adenotonsillectomy improve growth in children with obstructive adenotonsillar hypertrophy? J Int Med Res 31:84-87

27. Nieminen $P$, Löppönen $T$, Tolonen $U$, Lanning $P$, Knip M, Löppönen $H$ (2002) Growth and biochemical markers of growth in children with snoring and obstructive sleep apnoea. Pediatrics 109:e55

28. Cassano M, Russo G, Granieri C, Ciavarella D (2018) Modification of growth, immunologic and feeding parameters in children with OSAS after adenotonsillectomy. Acta Otorhinolaryngol Ital 38:124-130

29. Shatz A (2004) Indications and outcomes of adenoidectomy in infancy. Ann Otol Rhinol Laryngol 113:835-838
30. Ohayon MM, Carskadon MA, Guilleminault C, Vitiello MV (2004) Metaanalysis of quantitative sleep parameters from childhood to old age in healthy individuals: developing normative sleep values across the human lifespan. Sleep 27:1238-1239

31. Ezzat WF, Fawaz S, Abdelrazek Y (2010) To what degree does adenotonsillectomy affect neurocognitive performance in children with obstructive sleep apnea hypopnea syndrome due to adenotonsillar enlargement? ORL J Otorhinolaryngol Relat Spec 72:215-219

32. Afolabi OA, Alabi BS, Ologe FE, Dunmade AD, Segun-Busari S (2009) Parental satisfaction with post-adenotonsillectomy in the developing world. Int J Pediatr Otorhinolaryngol 73:1516-1519

33. Onakoya PA, Nwaorgu OGB, Abja UM, Kokong DD (2004) Adenoidectomy and tonsillectomy: is clotting profile relevant? Nigerian Journal of Surgical Research 6:34-36

34. Fasunla AJ, Onakoya PA, Ogunkunle OO, Mbam TT, Nwaorgu OG (2011) Routine electrocardiography request in adenoidectomy: is it necessary? Indian J Otolaryngol Head Neck Surg 63:330-335

35. Chervin RD, Clarke DF, Huffman JL, Szymanski E, Ruzicka DL, Miller V et al (2003) School performance, race and other correlates of sleep-disordered breathing in children. Sleep Med 4:21-27

36. Calhoun SL, Vgontzas AN, Mayes SD, Tsaoussoglou M, Sauder K, Mahr F et al (2010) Prenatal and perinatal complications: is it the link between race and SES and childhood sleep disordered breathing? J Clin Sleep Med 6:264-269

37. Li S, Jin X, Yan C, Wu S, Jiang F, Shen X (2010) Habitual snoring in schoolaged children: environmental and biological predictors. Respir Res 11:144

38. Gokdemir Y, Ersu R (2016) Sleep disordered breathing in childhood. Eur Respir Rev. 25:48-53

39. Chervin RD, Hedger K, Dillon JE, Pituch KJ (2000) Pediatric sleep questionnaire (PSQ): validity and reliability of scales for sleep-disordered breathing, snoring, sleepiness and behavioral problems. Sleep Med 1:21-32

40. Montgomery-Downs HE, Jones VF, Molfese VJ, Gozal D (2003) Snoring in preschoolers: associations with sleepiness, ethnicity, and learning. Clin Pediatr (Phila) 42:719-726

41. Rosen CL, Larkin EK, Kirchner HL, Emancipator JL, Bivins SF, Surovec SA et al (2003) Prevalence and risk factors for sleep-disordered breathing in 8- to 11year-old children: association with race and prematurity. J Pediatr 142:383-389

\section{Publisher's Note}

Springer Nature remains neutral with regard to jurisdictional claims in published maps and institutional affiliations.

\section{Submit your manuscript to a SpringerOpen ${ }^{\circ}$ journal and benefit from:}

- Convenient online submission

- Rigorous peer review

- Open access: articles freely available online

- High visibility within the field

- Retaining the copyright to your article

Submit your next manuscript at $>$ springeropen.com 